\title{
THE EPIDEMIOLOGY OF INFLAMMATORY BOWEL DISEASE
}

\author{
COLONEL D M ROBERTS, MD, FRCP(Ed), MRCP(Lond)
}

\author{
Royal Army Medical College, London
}

The epidemiological study of inflammatory bowel disease (IBD) is made difficult by problems of case ascertainment although, in developed countries, hospital admission rates are probably acceptable as evidence (Evans and Acheson ${ }^{1}$ ). Many epidemiological surveys of ulcerative colitis (UC) were done before Crohn's colitis and ischaemic colitis were recognised as separate entities and are therefore of dubious quality. This article therefore concentrales on the more recently published work in which acceptable criteria for ascertainment and diagnosis have been used. Beclause of possible confusion due to special forms of acute ileitis such as those due to Yersinia enterocolitioa (Winblad $e{ }^{a} \mathrm{l}^{2}$ ) and the fish nematode larva Anisakis (Ishikura and Hayasaka ${ }^{3}$ ) surveys which include the syndrome of acute regional enteritis have been excluded.

\section{Ulcerative colitis}

\section{Geographical variations in incidence}

Table I shows the incidence of UC in various parts of the world, grouped into broad geographical areas. Ulcerative colitis appears to be most common in Nonthern Eunope but much less so in Southern Europe, with Eastern Europe occupying an intermediate position. On the American Continent, too, the incidence is higher in the north than in the south. Little is known of the incidence in Africa and Asia.

Table I

UIcerative colitis - incidence / 100,000 / year

\begin{tabular}{|c|c|c|c|}
\hline \multicolumn{2}{|c|}{ Area } & Year/s & Incidence \\
\hline NORTHERN EUROPE & $\begin{array}{l}\text { Copenhagen } \\
\text { Oxford } \\
\text { Malmö } \\
\text { Finland } \\
\text { Norway } \\
\text { Hamburg }\end{array}$ & $\begin{array}{l}1961-66 \\
1951-60 \\
1958-70 \\
1967 \\
1964-69 \\
1965\end{array}$ & $\begin{array}{l}7.3 \\
6.5 \\
6.4 \\
4.8 \\
3.3 \\
2.6\end{array}$ \\
\hline EASTERN EUROPE & $\begin{array}{l}\text { Rumania } \\
\text { Yugoslavia (Slovenia) } \\
\text { Yugoslavia (Celje) }\end{array}$ & $\begin{array}{l}1965 \\
1963 \\
1965\end{array}$ & $\begin{array}{l}2.8 \\
1.5 \\
1.4\end{array}$ \\
\hline SOUTHERN EUROPE & $\begin{array}{l}\text { Seville } \\
\text { Vienna } \\
\text { Iran }\end{array}$ & $\begin{array}{l}1966 \\
1965 \\
1965\end{array}$ & $\begin{array}{l}0.4 \\
0.3 \\
0.2\end{array}$ \\
\hline OTHERS & $\begin{array}{l}\text { Tel Aviv } \\
\text { Baltimore } \\
\text { New Zealand } \\
\text { Japan } \\
\text { Chile } \\
\text { Mexico }\end{array}$ & $\begin{array}{l}1961-70 \\
1965 \\
1950-66 \\
1965 \\
1965 \\
1965\end{array}$ & $\begin{array}{l}3.66 \\
3.5 \\
2.86 \\
2.1 \\
0.2 \\
0.2\end{array}$ \\
\hline
\end{tabular}


Crohn's disease

Table II shows the incidence of $\mathrm{CD}$ in various parts of the world. No gross geographical variations seem to occur, although the high figure reported from Malmö is interesting.

rable II

Crohn's disease - incidence / 100,000 / year

\begin{tabular}{|ll|l|l|}
\hline & Area & Year/s & Incidence \\
\hline & Clydesdale & $1961-70$ & 1.55 \\
UNITED KINGDOM & Gloucester & $1966-70$ & 1.5 \\
& London & 1961 & 1.0 \\
& Nottingham & $1958-61$ \& & 1.93 \\
& Oxford & $1968-72$ & 0.8 \\
& North East Scotland & $1951-60$ & $1955-68$ \\
& Average & & 2.2 \\
& Copenhagen & $1960-70$ & 1.5 \\
\hline \multirow{3}{*}{ SCANDINAVIA } & Finland & $1949-70$ & 1.29 \\
& Norway & $1964-69$ & 0.27 \\
& Sweden (Central) & $1956-67$ & 1.05 \\
& Sweden (Malmö) & $1958-73$ & 4.8 \\
& Average & & 1.98 \\
\hline OTHERS & Baltimore & $1960-63$ & 1.8 \\
& Basel & $1960-69$ & 1.6 \\
\hline
\end{tabular}

Regional variations in incidence

Few data are available, but regional variations probably occur, as demonstrated by the Hospital In-patient Enquiry Data for 1966-1967 shown in Table III (Barker and Gardner ${ }^{4}$ ). It may be significant that, in women at least, the UC and CD rates are correlated, East Anglia having the lowest rate for both and South East Wales the highest.

\section{Table III}

Female discharge rates (Hospital In-patient Enquiry Data)

\begin{tabular}{|l|l|l|}
\hline \multicolumn{1}{|c|}{ Inflammatory bowel disease } & \multicolumn{1}{c|}{ Region } & Rate \\
\hline CROHN'S DISEASE & $\begin{array}{l}\text { East Anglia } \\
\text { South East Wales }\end{array}$ & $\begin{array}{c}40 / \text { million } \\
79 / \text { million }\end{array}$ \\
\hline ULCERATIVE COLITIS & $\begin{array}{l}\text { East Anglia } \\
\text { South East Wales }\end{array}$ & $\begin{array}{c}66 / \mathrm{million} \\
155 / \mathrm{million}\end{array}$ \\
\hline
\end{tabular}

Sex and age

Both $\mathrm{UC}$ and $\mathrm{CD}$ are predominantly diseases of young adults as typified by the data on CD from Malmö (Brahme $e t a l^{5}$ ) and on UC from Tel Aviv (Gilat $e t$ $a l^{8}$ ) (Figures 1 and 2). 


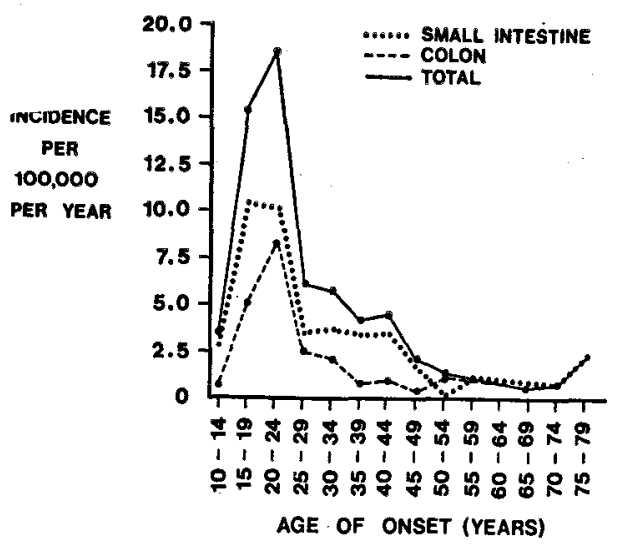

Fig. 1. Incidence of Crohn's disease in Malmö (Brahme et al 1975).

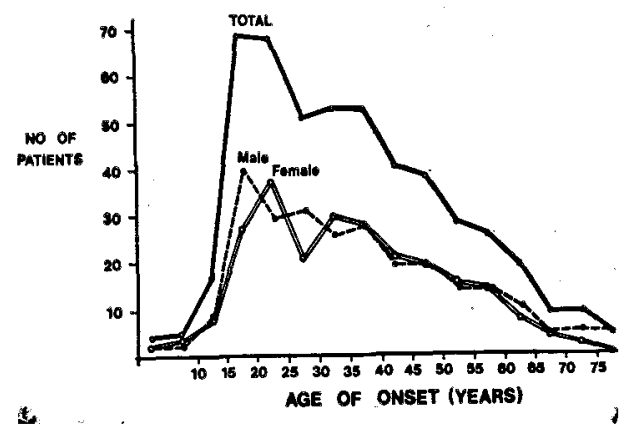

Fig. 2. Incidence of Ulcerative colitis in Tel Aviv (Gilat et al 1974).

Several reports (Brahme et $a l^{5^{2}}$ Evans and Acheson ${ }^{1}, \mathrm{Kyll}^{7}$, Linden and Möller $^{8}$, Norten et $a l^{9}$, Smith et $a l^{10}$, Tresadern et $a l^{11}$ ) suggest that for both diseases there may be a "secondary peak" in old age as shown in Figure 3 for Chicago

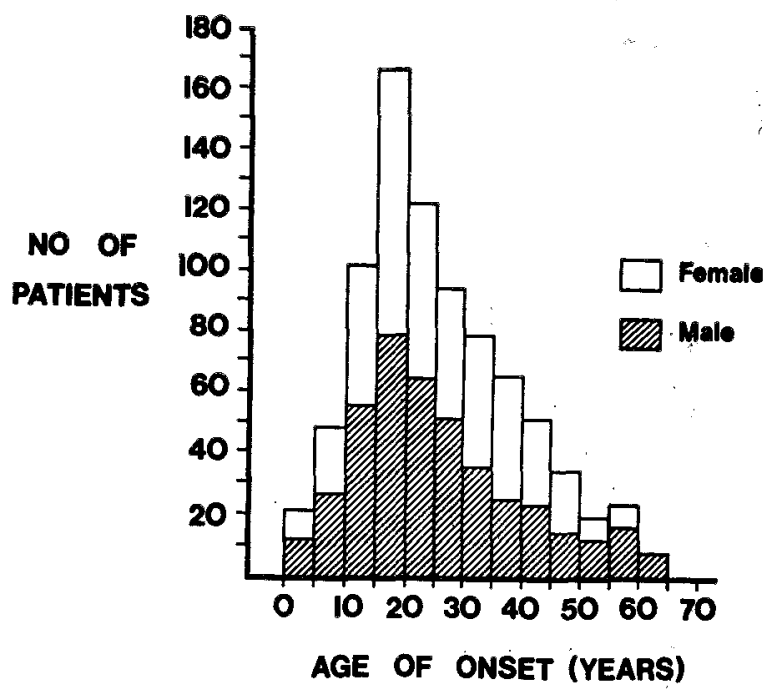

Fig. 3. Incidence of Ulcerative colitis in Chicago showing "secondary peak" in old age (Rogers et al 1971).

(Rogers et $a l^{12}$ ). For CD there is some evidence that the "secondary peak" is caused largely by an increased incidence in colonic disease which also tends to affect more women than men. 
Figures 4 and 5 show the relative sex incidence of the two diseases in various areas. For both diseases female preponderance seems to be most marked in the United Kingdom.
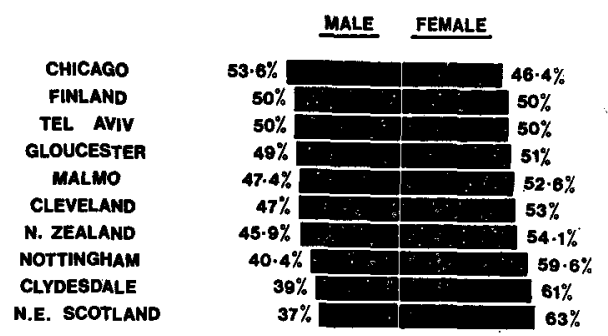

Fig. 4. The sex incidence of Crohn's disease in various areas.

It is often difficult to determine that differences apparently due to race are not in fact due to environmental factors. Nevertheless, the weight of the evidence strongly suggests that both diseases are approximately four-fold more common in Jews and five-fold less common in Negroes than in other ethnic groups (Brahme et $a l^{5}$, Evans et $a l^{1}$, Monk et $a l^{13}$, Mosbech ${ }^{14}$, Novis et $a l^{15}$, Rogers et $a l^{12}$ ).

The extraordinary thing-if one accepts that epidemiological trends reflect aetiological factors-is that the racial pattern for the two diseases appears to be the same.

\section{Effects of other demographic factors}

Both UC and CD seem to be more common in urban than in rural areas (Couchman and Wigley ${ }^{16}$, Linden and Möller ${ }^{8}, \mathrm{Kyll}^{7}$, Monk $\left.e a^{13}\right)$ the same phenomenon was probably observed in Chicago (Rogers et $a l^{12}$ ) where both diseases were found to be less common among farmers than others. No such difference, however, was noted for CD in Central Sweden (Norten et $a l^{9}$ ).

Evidence on the effect of social status or occupation is sparse and conflicting (Kyle ${ }^{7}$, Monk et $a l^{13}$ ).

Some reponts (Rogers et $a l^{12}$, Monk et $a l^{13}$ ) have suggested that IBD may be more common among those of higher educational attainment, but these data are open to several other possible interpretations.

\section{Is the incidence of inflammatory bowel disease changing?}

For $\mathrm{CD}$, the only reliable information comes from Europe and is summarised in Figure 6. In both Nottingham and North East Scotland the reported increase in females greatly exceeds that in males whereas the reverse is true for Central Sweden. In Scotland there was a remarkable 12-fold increase in the incidence of colonic disease. In Clydesdale, compared with a 33 per cent increase in small bowel cases, there was a 100 per cent increase in purely large bowel cases with a marked female predominance (specially over the age of 50 years, when the sex ratio was eight females to one male). 
Overall, the incidence of $\mathrm{CD}$ is increasing at a rate of 250 per cent per decade.

The little reliable information about the changing incidence of UC is represented in Figure 7. The incidence may be on the increase in most areas.

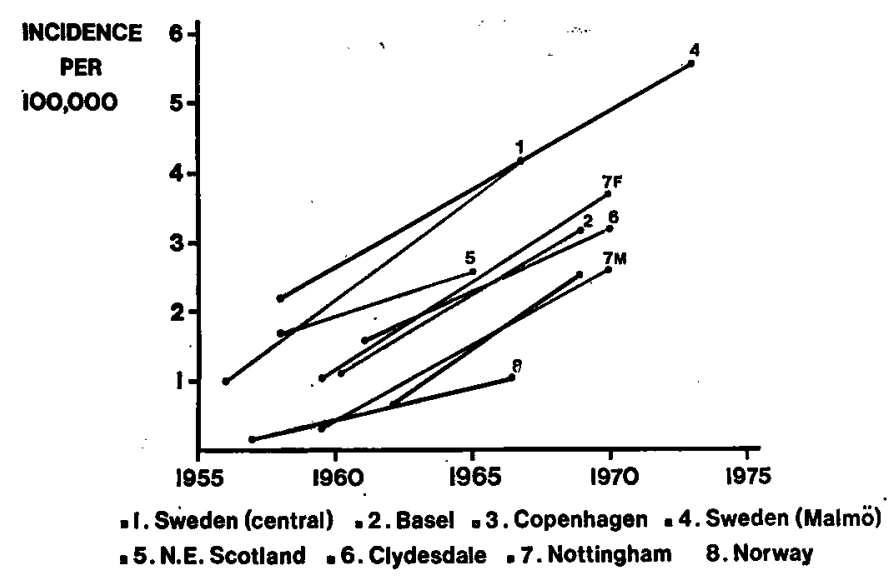

Fig. 6. The changing incidence of Crohn's disease in Europe.

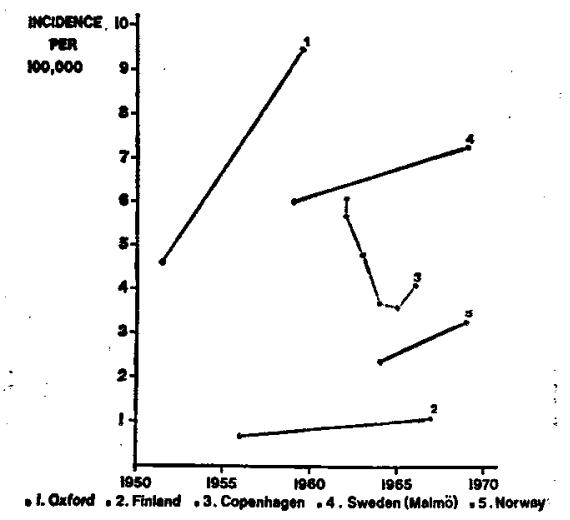

Fig 7. The changing incidence of Ulcerative colitis in Europe.

Arguments that these increases may be more apparent than real are difficult to completely refute but (although space does not permit any elaboration) they are unlikely to account for large assessment errors.

\section{Other possible epidemiological clues}

a. Miller $e t a l^{17}$ looked for "time-space clustering" as evidence for an inefective aetiology of $\mathrm{CD}$ in the Nottingham area and found none.

b. Gardner and James ${ }^{18}$ reported that patients with $\mathrm{CD}$ ate significantly more cornflakes and wheat than controls.

c. Table IV shows the wide geographical variation in the incidence of other conditions known to be associated with UC. The significance of these variations is obscure. 
Table IV

Ulcerative colitis - incidence of extracolonic manifestations

\begin{tabular}{|l|l|c|}
\hline \multicolumn{1}{|c|}{ Manifestation } & \multicolumn{1}{|c|}{ Area } & Percentage \\
\hline & Australia & 14.0 \\
LIVER DISEASE & Czechoslovakia & 9.1 \\
& England & 7.4 \\
& Israel & 3.2 \\
& Spain & 2.4 \\
& Turkey & 20.0 \\
\cline { 3 - 4 } & Great Britain (variously & 7.4 \\
ARTHROPATHY & reported) & 2.7 \\
(including ankylosing spondylitis) & Czechoslovakia & 6.6 \\
& Israel & 5.2 \\
& Spain & 4.8 \\
& Turkey & 11.5 \\
\hline EYES DISEASES (Approximate) & & 8.3 \\
\hline SKIN DISEASES (Approximate) & & 0.5 \\
\hline
\end{tabular}

\section{REFERENCES}

1. Evans, $J$ G and Acheson, E $D$ (1965). An epidemiological study of ulcerative colitis and regional enteritis in the Oxford Area. Gut 6, 311-324.

2. Winblad, S, Nihlen, B AND Sternby, N H (1966). Yersinia enterocolitica (Pasteurella X) in human enteric infections. British Medical Journal ii 1363.

3. IsHIKURA, H AND HAYASAKA, H (1967). Acute regional ileitis at Iwanai and Hokkaido, with special reference to intestitinal Anisakiasis. Sapporo Medical Journal 32, 183-196.

4. Barker, D J AND GARDNER, M J (1974). Epidemiology of Crohn's Disease. Lancet ii, 1140.

5. 'Brahme, F, Lindstrom, C AND Wenckert, A (1975). Crohn's Disease in a defined population. Gastroenterology 69, 342-351.

6. Gillat, $T$, et al (1974). Ulcerative colitis in the Jewish population of Tel Aviv Jafo. Gastroenterology 66, 335-342.

7. KYLE, J (1971). An epidemiological study of Crohn's disease in North East Sootland. Gastroenterology 61, 826-833.

8. Linden, G AND MOLLER, C (1971). Ulcerative colitis in Finland. Diseases of the Colon and Rectum 14, 264-266.

9. Norten, B J, Krause, U and Bergman, L (1970). An epidemiological study of Ctohn's disease. Scandinavian Journal of Gastroenterology 5, 385-390.

10. SMith, I S et al (1975). Epidemiologioal aspects of Crohn's disease in Clydesdale 1961-1970 Gut 16, 62-67.

11. Tresadern, J C, Gear, M W L and Nicol, A (1973). An epidemiological study of regional enteritis in the Gloucester Area. British Journal of Surgery 60, 366-368.

12. Rogers, B H G, Clark, L M and KirSNer, J B (1971). The epidemiological and demographic characteristics of inflammatory bowl disease: an analysis of a computerised file of 14,000 patients. Journal of Chronic Diseases 24, 743-773.

13. MonK, M et al (1969). An epidemiological study of ulcerative colitis and regional enteritis among adults in Baltimore. Gastroenterology 56, 847-857.

14. MosBeCH, J (1960). Mortality from ulcerative colitis in Denmark. Gastroenterology 39, 690-693.

15. Novis et al (1975). Incidence of Crohn's disease at Groote Schuur Hospital during 19701974. South African Medical Journal 49, 693-697.

16. Couchman, K G AND WIGLEY, R D (1971). The distribution of the systemic connective tissue diseases, ulcerative colitis and Crohn's disease in New Zealand: an Analysis of hospital admission statistics. New Zealand Medical Journal 74, 2311-233.

17. Miller et al (1975). Crohn's disease in Nottingham: a search for time-space clustering Gut. 16, 454-457.

18. GARDNer, M J and JAMES, A H (1977). Breakfast and Crohn's disease. British Medical Journal ii, 826-827. 